\title{
Some aspects of the ecological niche of chironomids associated with submersed aquatic macrophytes in a tailwater
}

\author{
Maria Grzybkowska ${ }^{1, *}$, Joanna Leszczyńska ${ }^{1}$, Łukasz Głowacki ${ }^{1}$, Eliza Szczerkowska-Majchrzak ${ }^{1}$, \\ Małgorzata Dukowska ${ }^{1}$ and Elżbieta Szeląg-Wasielewska ${ }^{2}$ \\ ${ }^{1}$ Department of Ecology and Vertebrate Zoology, Faculty of Biology and Environmental Protection, University of Łódź, \\ 12/16 Banacha Str., 90-237 Łódź, Poland \\ ${ }^{2}$ Department of Water Protection, Faculty of Biology, Adam Mickiewicz University in Poznań, 6 Uniwersytet Poznański Str., \\ 61-614 Poznań, Poland
}

Received: 28 October 2019 / Accepted: 15 April 2020

\begin{abstract}
High values of chironomids' production were recorded and analysed in the tailwater of a dam reservoir located on a large river. The values resulted from submersed aquatic macrophytes (SAM) patches that appear on the bottom in summer, as an effect of a specific discharge pattern through the dam. Abundant and taxonomically rich chironomid assemblages develop there, but their populations display different spatial and trophic preferences, which are the main topic of our interest here. We focused on dominant taxa of Orthocladius/Cricotopus spp., Chironomus riparius Meigen and Glyptotendipes cauliginellus (Kieffer), whose abundance and biomass exceeded $90 \%$ of all chironomids inhabiting the SAMs. The developmental time of their aquatic stages (cohort production interval - CPI) and thus production, and production to biomass ratio $(\mathrm{P}: \mathrm{B})$ differed considerably. A P:B ratio of 13.8 was estimated for the first taxon, a mid-body size scraper living on stems and leaves of SAMs. In contrast, P:B ratios of 5.2-7.7 were assessed for the second and third taxa, rather large body size benthic gathering collectors inhabiting the roots of SAMs. The main food categories of gathering collectors were particulate organic matter trapped by the roots, while scrapers fed on algae developing on leaves and stems.
\end{abstract}

Keywords: Aquatic plants / dominant chironomid taxa / habitat / trophic preferences / production

\begin{abstract}
Résumé - Quelques aspects de la niche écologique des chironomes associés aux macrophytes aquatiques immergés dans une eau de restitution d'un barrage. Des valeurs élevées de la production de chironomes ont été enregistrées et analysées dans les eaux de restitution d'un réservoir de barrage situé sur une grande rivière. Ces valeurs sont le résultat de patchs de macrophytes aquatiques submergés (SAM) qui apparaissent sur le fond en été, sous l'effet d'un modèle spécifique de restitution en eau du barrage. Des communautés de chironomes abondantes et taxonomiquement riches s'y développent, mais leurs populations présentent des préférences spatiales et trophiques différentes, qui sont le principal sujet d'intérêt ici. Nous nous sommes concentrés sur les taxons dominants d'Orthocladius/Cricotopus spp., Chironomus riparius Meigen et Glyptotendipes cauliginellus (Kieffer), dont l'abondance et la biomasse dépassent $90 \%$ de tous les chironomides vivant dans les SAM. Le temps de développement de leurs stades aquatiques (intervalle de production de la cohorte - IPC) et donc la production, et le rapport production/biomasse (P:B) différaient considérablement. Un rapport P:B de 13,8 a été estimé pour le premier taxon, un racleur-brouteur de taille moyenne vivant sur les tiges et les feuilles des SAM. En revanche, des rapports P:B de 5,2 à 7,7 ont été évalués pour les deuxième et troisième taxons, des collecteurs benthiques de taille assez importante vivant sur les racines des SAM. Les principales catégories de nourriture des collecteurs benthiques étaient les matières organiques particulaires piégées par les racines, tandis que les racleurs-brouteurs se nourrissaient d'algues se développant sur les feuilles et les tiges.
\end{abstract}

Mots clés : Plantes aquatiques / taxons de chironomes dominants / habitat / préférences trophiques / production

\footnotetext{
*Corresponding author: maria.grzybkowska@biol.uni.lodz.pl
} 


\section{Introduction}

Compared to more natural river sections, reservoir tailwaters are strongly affected by alterations impacting the development of many organisms, including macrophytes and macroinvertebrates. These alterations concern the magnitude, frequency, timing, duration and rate of change of the hydrological regime (Van Donk and Van de Bund, 2002), which may occasionally cause tailwaters to suddenly receive large amounts of nutrients of reservoir origin. In such cases, the resulting environmental conditions stimulate the development of submersed aquatic macrophytes (SAM) patches. SAMs appear at the bottom of the tailwater of a large lowland reservoir's dam (Jeziorsko Reservoir, Warta River) in the summer of each year. Aquatic plants provide an excellent surface for epiphyton and epiphytic consumers and are also beneficial for large populations of pelophilous macrobenthic fauna, owing to the deposition of organic matter (Grzybkowska et al., 2003, 2017). Dipterans, such as Chironomidae (non-biting midges) and Simuliidae belong to this group.

Chironomids, with a merolimnic life history (composed of an aquatic larval development and a terrestrial adult life (Armitage et al., 1995)), often develop in lake and river sediment with high organic content and their production is an important parameter for understanding the structure and function of freshwater ecosystems (Vellend, 2016). During the habitat shift from the aquatic larval to airborne adult stage, chironomid pupae substantially contribute to the nutrient transfer from benthic habitats to pelagic food webs (Vander Zanden et al., 2016; Wagner et al., 2012; Lik et al., 2017), making Chironomidae a keystone group in river and lake food energy circulation, firstly as primary consumers and secondly as prey of other invertebrates and fish (Grzybkowska et al., 2018). However, while many stenotopic taxa are highly productive only in specific ecological conditions, the preferences of dominant and plastic taxa, which differ in life history and body size (Strayer, 1991; Krebs, 2014), are less well understood. We examined the spatial and trophic preferences of the three dominant chironomid taxa inhabiting the same aquatic plant ecosystem in order to determine the extent to which these differ.

We undertook a comprehensive study of the community structure and life history traits of the three taxa inhabiting the tailwater of the Jeziorsko Reservoir. The basic question addressed was "What is the function of chironomids in the circulation of matter and flow of energy in such an unusually rich riverine habitat?' Consequently, the specific aims of the study were:

- to present the structure of the chironomid assemblages associated with submersed aquatic macrophytes and their main population features, such as abundance and biomass, - to show their trophic preferences,

- to determine the specific environmental drivers that enable such high chironomid production in this diverse river stretch.

\section{Study area}

The study was conducted in the River Warta, whose sources rise $380 \mathrm{~m}$ above sea level, is $808 \mathrm{~km}$ long and empties into the River Oder at $13 \mathrm{~m}$ above sea level. The Warta slope ranges from 2.0 to $1.0 \%$ in the upper course, and from 0.3 to

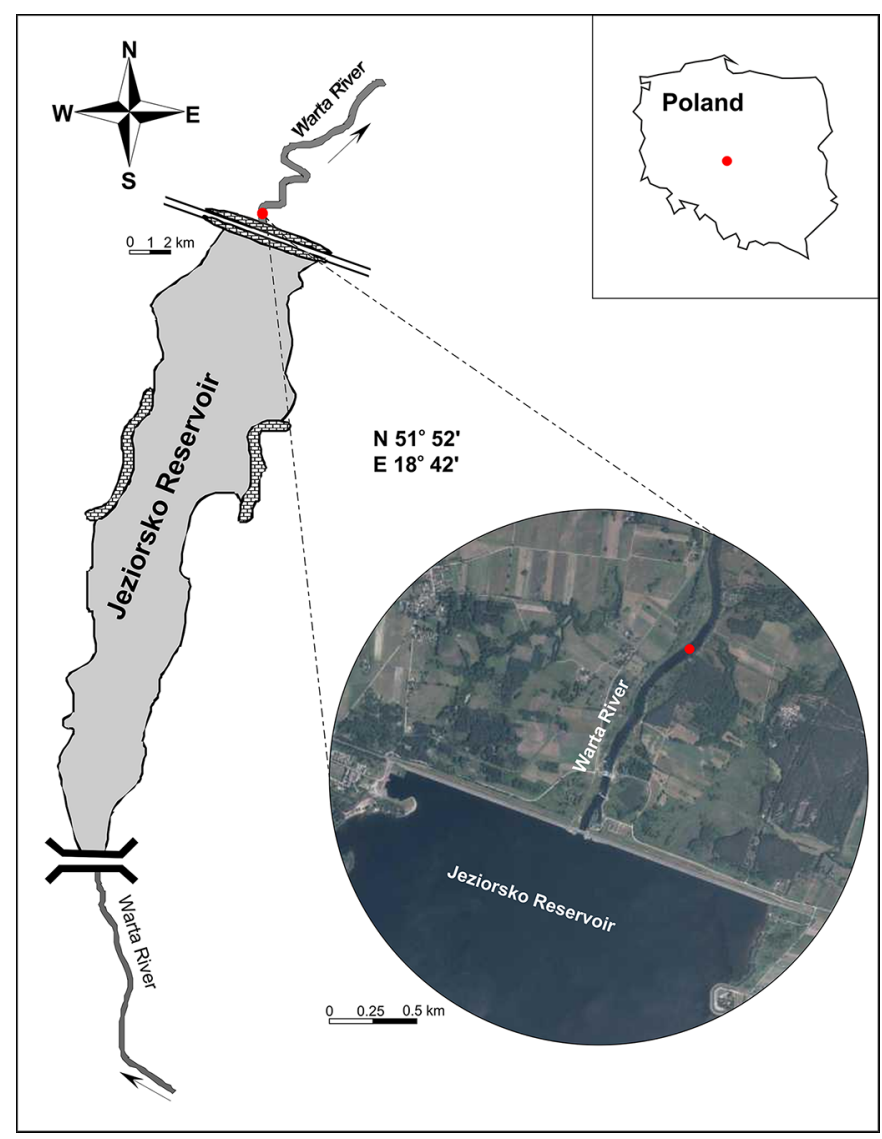

Fig. 1. Localization of study area.

$0.1 \%$ in the middle and lower courses. The river's catchment area is ca. $53,710 \mathrm{~km}^{2}$ (IMGW, 2007). Samples were collected in a fifth stream order section $\left(51^{\circ} 52^{\prime} \mathrm{N}, 18^{\circ} 42^{\prime} \mathrm{E}\right)$ (Strahler, 1957) of this lowland alluvial river, about $1.5 \mathrm{~km}$ downstream of the Jeziorsko Reservoir (Fig. 1), which started functioning in 1986. The change in the stream order of the study site, in comparison to our previous papers (Grzybkowska and Głowacki, 2011; Grzybkowska et al., 2017, 2018), results from the availability of more precise and recent information on the hydrographic partitions of Poland (Czarnecka, 2005). In the tailwater, the Warta River was approximately $70 \mathrm{~m}$ wide, with a maximum depth of $1.2 \mathrm{~m}$. In this study, as in previous investigations (Grzybkowska et al., 2003, 2017) we examined a macrophyte habitat located between the marginal zone and the mid-river channel. This habitat was structured mainly by the aquatic plant species of sago Stuckenia pectinata (L.) Börner (Fig. 1). The abundance of SAM largely depends on discharge regulations. In 2004, during low summer discharge, we recorded a larger amount and coverage of vegetation ( $149.4 \mathrm{~g}$ dry weight $\mathrm{m}^{-2}$, covering nearly $56 \%$ of the river bed) than observed in previous investigations (Grzybkowska et al., 2017).

\section{Material and methods}

\subsection{Sampling}

Samples were collected from May to August in 2004 (9 sampling dates in 103 days). On each occasion, river width, 
M. Grzybkowska et al:: Knowl. Manag. Aquat. Ecosyst. 2020, 421, 22

Table 1. Mean and ranges of investigated environmental parameters in the macrophytes of the tailwater of the Warta River. T - water temperature, $\mathrm{O}_{2}$ - dissolved oxygen, TN - total nitrogen, TP - total phosphorus, CPOM - coarse particulate organic matter, FPOM - fine particulate organic matter, TPOM - transported particulate organic matter, SAM - submersed aquatic macrophytes; $d \mathrm{w}-\mathrm{dry}$ weight.

\begin{tabular}{|c|c|c|c|c|c|c|c|c|}
\hline \multirow[b]{2}{*}{ Chironomid taxa } & \multicolumn{8}{|c|}{ Parameter } \\
\hline & $\begin{array}{c}\mathrm{T} \\
\left({ }^{\circ} \mathrm{C}\right)\end{array}$ & $\begin{array}{c}\mathrm{O}_{2} \\
\left(\mathrm{mg} \mathrm{L}^{-1}\right)\end{array}$ & $\begin{array}{c}\mathrm{TN} \\
\left(\mathrm{mg} \mathrm{L}^{-1}\right)\end{array}$ & $\begin{array}{c}\mathrm{TP} \\
\left(\mathrm{mg} \mathrm{L}^{-1}\right)\end{array}$ & $\begin{array}{c}\mathrm{CPOM} \\
\left(\mathrm{g} \mathrm{d} \mathrm{w} \mathrm{m}^{-2}\right)\end{array}$ & $\begin{array}{c}\text { FPOM } \\
\left(\mathrm{g} \mathrm{d} \mathrm{w} \mathrm{m}^{-2}\right)\end{array}$ & $\begin{array}{c}\text { TPOM } \\
\left(\mathrm{g} \mathrm{d} \mathrm{w} \mathrm{m}^{-2}\right)\end{array}$ & $\begin{array}{c}\text { SAM } \\
\left(\mathrm{g} \mathrm{d} \mathrm{w} \mathrm{m}^{-2}\right)\end{array}$ \\
\hline Mean & 18.0 & 8.8 & 1.5 & 0.1 & 175 & 3035 & 9 & 149.4 \\
\hline Range & $15.6-20.3$ & $7.9-10.0$ & $0.8-1.9$ & $0.1-0.1$ & $52-522$ & $1010-4881$ & $1.3-32.6$ & $0-245.6$ \\
\hline
\end{tabular}

water depth, water temperature, dissolved oxygen and percentage of substrate covered by vascular plants were measured or estimated. Nutrient concentrations (amounts of total nitrogen and phosphorus in water column) were obtained from the Voivodeship Inspectorate for Environmental Protection in Lodz (VIEP Lodz, 2019). A detailed description of selected environmental parameters investigated in the study site is presented in Table 1.

To estimate the biomass of macrophytes growing in the study site $(40 \times 2.5 \mathrm{~m})$, a special frame $(0.5 \times 0.7 \mathrm{~m})$ was placed randomly on the river bottom in the macrophyte zone (at a mean depth of about $0.4 \mathrm{~m}$ ) and all $S$. pectinata specimens within the frame were collected. This procedure was repeated three times on each sampling occasion. Then, in the laboratory, macrophytes were dried for $24 \mathrm{~h}$ at $65^{\circ} \mathrm{C}$ to estimate their dry weight per $1 \mathrm{~m}^{2}\left(\mathrm{~g} \mathrm{dw} \mathrm{m}^{-2}\right)$.

Riverine invertebrates were sampled by collecting five subsamples of the epiphytic fauna settled on the stems and leaves of $S$. pectinata (sago), which constituted one of the two macroinvertebrate habitats, on each sampling occasion. A subsample consisted of three fragments of stems (about $200 \mathrm{~mm}$ long), which were placed in plastic containers $(250 \mathrm{~mm}$ in height, $100 \mathrm{~mm}$ in diameter) below the water surface, cut off and preserved in $4 \%$ formalin. In the laboratory, all invertebrates associated with macrophytes were washed off, sorted manually, identified to the lowest taxonomic level, counted, and weighed (wet weight). Later, the data were recalculated to estimate the biomass of epiphytic invertebrates per $1 \mathrm{~m}^{2}$ of $S$. pectinata covering the substrate on each sampling occasion.

Each benthic sample, which contained mainly the roots of sago and was the second macroinvertebrate habitat, consisted of five subsamples that were collected from uniformly distributed points within the habitat, using a tubular sampler (a catching area of $10 \mathrm{~cm}^{2}$ ). In the laboratory, invertebrates were washed on sieves (mesh size $0.5 \mathrm{~mm}$ ) to separate them from detritus and benthic sediments and preserved in plastic containers in $4 \%$ formalin. Subsequently, organisms were identified to the lowest taxonomic level, counted and weighed (wet weight). These data were used to estimate the biomass of zoobenthos $\left(\mathrm{g} \mathrm{m}^{-2}\right)$, including the three dominant chironomid taxa that were the focus of the analysis.

The benthic samples remaining after sorting the invertebrates were used to estimate the content of benthic particulate organic matter (BPOM) divided into two fractions: $>1 \mathrm{~mm}$ (coarse, CPOM) and $<1 \mathrm{~mm}$ (fine, FPOM) (Petersen et al., 1989). The organic matter was dried at $60^{\circ} \mathrm{C}$ for $2 \mathrm{~d}$, weighed, ashed at $600^{\circ} \mathrm{C}$ for $2 \mathrm{~h}$, and reweighed.
To determine the quantity of transported particulate organic matter (TPOM), three water samples of $0.01 \mathrm{~m}^{3}$ were collected. In the laboratory, samples were filtered through preweighed Whatman GF/C glass-fiber filters $(1.2 \mu \mathrm{m})$. TPOM of the samples was subsequently analyzed as described for BPOM.

\subsection{Production estimation}

Special attention was paid to three dominant chironomid taxa: the large-sized benthic $C$. riparius (mean $3.57 \mathrm{mg}$ wet weight $-\mathrm{mg} \mathrm{w} \mathrm{w}=0.714 \mathrm{mg}$ dry weight $-\mathrm{mg} \mathrm{d} \mathrm{w})$ and $G$. cauliginellus (mean $4.48 \mathrm{mg} \mathrm{w} \mathrm{w}=0.896 \mathrm{mg} \mathrm{d} \mathrm{w}$ ), belonging to the Chironominae subfamily (Chironomini tribe) (Moller Pillot, 2009), and the mid-sized epiphytic Orthocladius/ Cricotopus spp. (mean $0.27 \mathrm{mg} \quad$ w w $=0.054 \mathrm{mg} \quad \mathrm{d} \quad \mathrm{w}$ ), belonging to the subfamily Orthocladiinae (Fig. 2). Mean weight standards were calculated based on all specimens of each larval instar collected throughout the study period. The size-frequency method (Hynes and Coleman, 1968) as modified by Hamilton (1969) and Benke (1979) was used to estimate production by the dominant chironomid taxa. Larval body length was measured to the nearest $0.1 \mathrm{~mm}$, using a stereomicroscope Nikon SMZ1000 with ocular micrometers, and individuals were grouped into $0.5 \mathrm{~mm}$ or $1 \mathrm{~mm}$ length classes as suggested by Cushman et al. (1978). Mean theoretical body weight of each size class was calculated using the equations presented in Konstantinov (1958a), Mackey (1977) and Nolte (1990). To estimate production, the obtained P-value must be further multiplied by $365 / \mathrm{CPI}$, where CPI is the mean cohort production interval (Benke, 1979). As it was impossible to estimate CPIs from field data, the Mackey (1977) and Konstantinov (1958b) regression equations, which predict larval development times from temperature were used to estimate the CPIs for chironomid taxa:

$$
1 / D=a+b T
$$

where $T-$ temperature, $D-$ development time (in days), $a-$ intercept, $b-$ slope.

Since Mackey's and Konstantinov's equations were based mainly on laboratory data, the CPIs calculated for chironomid species were arbitrarily doubled to account for some degree of environmental resistance, such as competition, food storage, etc., as suggested by Benke et al. (1984). For further details see Grzybkowska and Witczak (1990). In Table 2, the production of particular chironomid taxa and their P:B ratio (Production: Biomass ratio) are presented; it has been empirically 


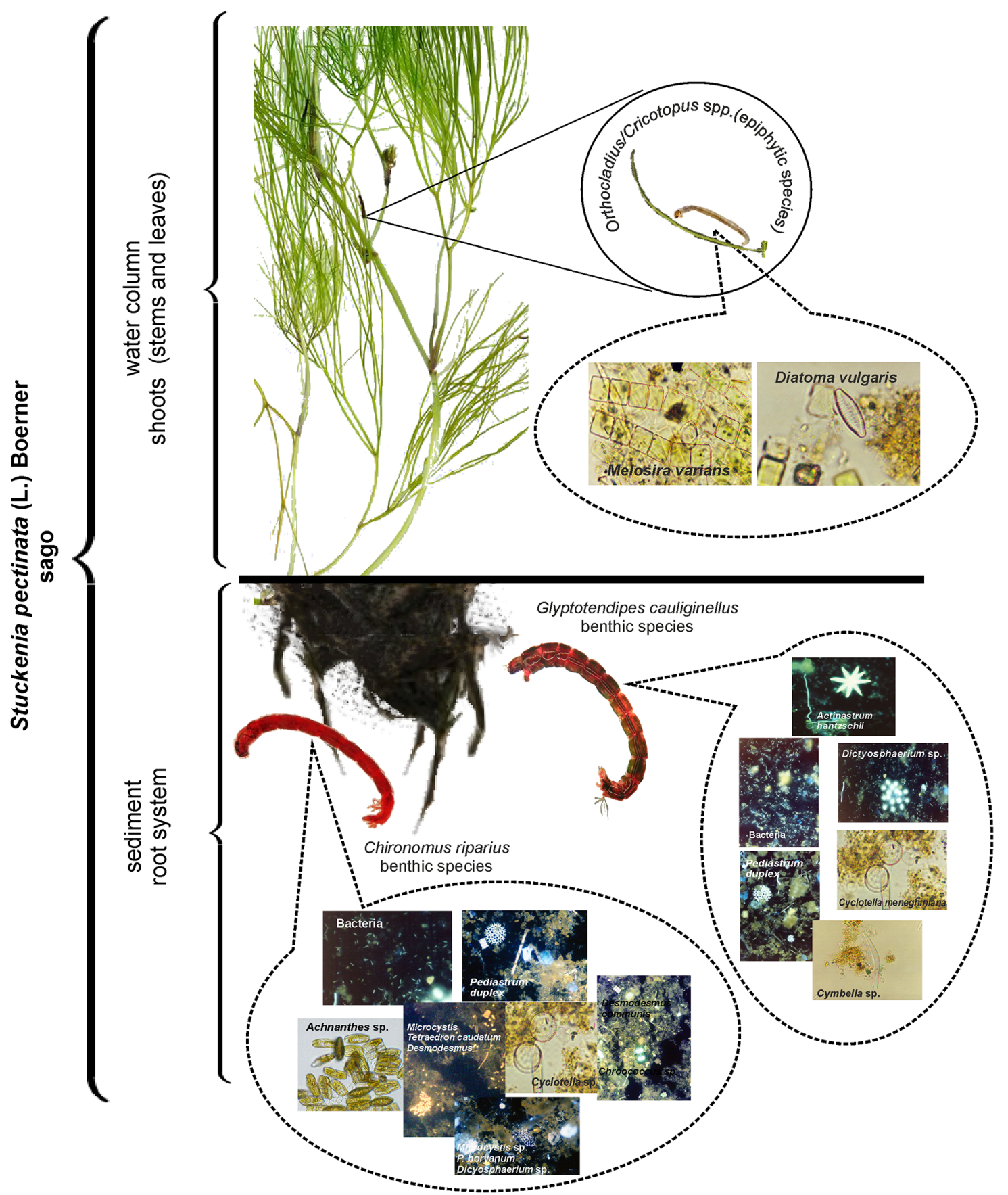

Fig. 2. Submersed aquatic macrophyte of the tailwater of the Warta River, sago, Stuckenia pectinata, with its dominant dwellers: epiphytic scrapers Orthocladius/Cricotopus spp. and benthic gathering collectors: Chironomus riparius Meigen and Glyptotendipes cauliginellus (Kieffer). Below each midge, its diet composition in a bubble is specified.

determined that P:B for one generation equals 5 for many chironomid species and many other macroinvertebrate taxa (Waters, 1977). The calculations of chironomid production cover the 103 day study period, with mean water temperature of ca. $17^{\circ} \mathrm{C}$.

Algae and bacteria in the gut contents were examined by microscope (Nikon Eclipse 50i, Olympus BX60) and epifluorescence microscopy (magnification 1500x) on black Nuclepore filters (pore size $0.2 \mu \mathrm{m}$ ) after staining cells with the fluorochrome DAPI (Porter and Feig, 1980).

\subsection{Statistical analysis}

Correlation coefficients between biomass values of the three chironomid species and environmental variables' values were calculated to determine whether any of them were statistically significant. Because the distributions of many of the variables' values were non-normal (as checked with the Shapiro-Wilks test) non-parametric Spearman rank correlation (rather than parametric Pearson correlation) was used. Analysis was performed using STATISTICA 10.0 (StatSoft, 2011). 
Table 2. Mean and ranges (in brackets) of the density $\left(\mathrm{N}\right.$ ind. $\left.\mathrm{m}^{-2}\right)$, biomass $\left(\mathrm{B} \mathrm{g} \mathrm{d} \mathrm{w} \mathrm{m}{ }^{-2}\right)$, production $\left(\mathrm{Pg} \mathrm{d} \mathrm{w} \mathrm{m}^{-2} \mathrm{yr}^{-1}\right)$ and $\mathrm{P}: \mathrm{B}($ turnover ratio) of dominant chironomid larvae in the macrophytes of the tailwater of the Warta River over the study period. $\mathrm{d} w-\mathrm{dry}$ weight.

\begin{tabular}{llll}
\hline & \multicolumn{3}{c}{ Parameters } \\
\cline { 2 - 4 } Chironomid taxa & \multicolumn{1}{c}{$\mathrm{N}$} & \multicolumn{1}{c}{$\mathrm{B}$} & $\mathrm{P}$ \\
\hline Orthocladius/Cricotopus spp. & $43333(1954-107534)$ & $99.159(8.568-176.471)$ & 1372.361 \\
Chironomus riparius Meigen & $933(150-3100)$ & $10.880(3.600-31.242)$ & 56.598 \\
Glyptotendipes cauliginellus (Kieffer) & $544(0-1900)$ & $6.870(0-22.800)$ & 5.661 \\
\hline
\end{tabular}

Epiphyton

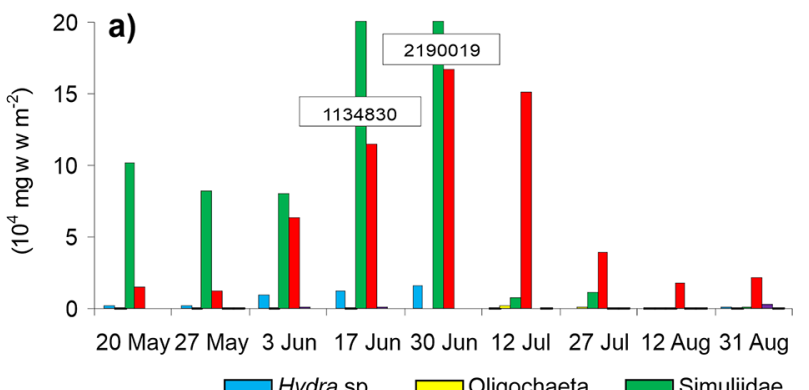

18

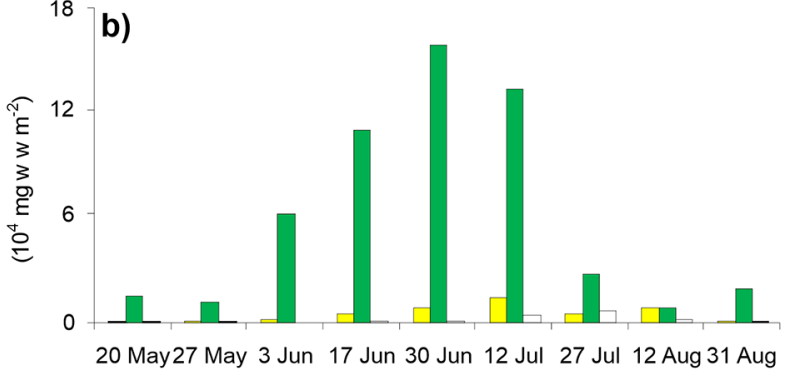

Benthos

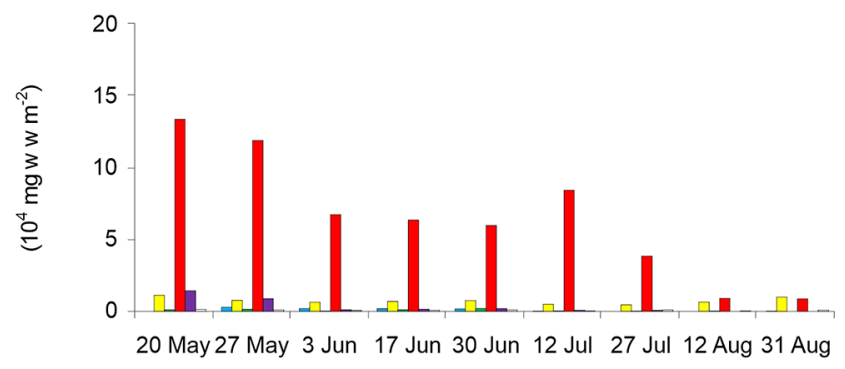

$\square$ Chironomidae $\square$ Trichoptera $\square$ others

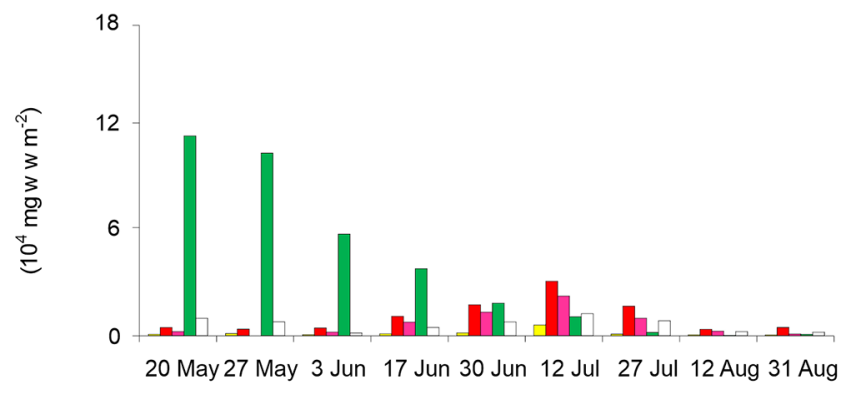

Fig. 3. Seasonal dynamics of the biomass $\left(\mathrm{mg} \mathrm{w} \mathrm{w} \mathrm{m}^{-2}\right.$ ) of dominant macroinvertebrates (a) and chironomids (b) in epiphyton and benthos.

\section{Results}

\subsection{Fauna associated with macrophytes}

In the macrophyte habitat, abundant macroinvertebrate fauna was recorded: mean total epiphytic biomass was $472.9 \mathrm{~g} \mathrm{~d} \mathrm{w} \mathrm{m}^{-2}$, while benthic biomass was $76.8 \mathrm{~g} \mathrm{~d} \mathrm{w} \mathrm{m}^{-2}$. The dominant epiphytic taxa were dipterans: Simuliidae and Chironomidae, which constituted $84.7 \%$ and $14.1 \%$, respectively, of total epiphytic macroinvertebrate assemblage biomass. The contribution of chironomids to the benthic macroinvertebrate assemblage biomass was similar, reaching $83.7 \%$, while that of simuliids only was $0.8 \%$. Other substantial benthic organisms were Oligochaeta $(9.3 \%)$ and Trichoptera (4.1\%) (Fig. 3a).

Among chironomids, Orthocladius/Cricotopus spp. (Orthocladiinae scrapers) were numerically dominant, and achieved the highest share in both epiphytic and benthic assemblages, yet their domination in the former $(90.7 \%$ of total chironomid biomass) was much higher than in the latter
(60.4\%). In the benthos, Chironomini, such as $C$. riparius and G. cauliginellus (both gathering collectors), were of some importance, comprising $16.9 \%$ and $10.7 \%$ of total biomass of chironomids, respectively (Fig. 3b).

Other taxa inhabiting both the epiphytic and benthic habitats were represented by Chironomini, such as Polypedilum sp. and Dicrotendipes sp. (gathering collectors), Parachironomus arcuatus (predators), Tanytarsini (filtering collectors): Tanytarsus sp., Paratanytarsus sp., Cladotanytarsus sp. and Orthocladiinae: Rheocricotopus sp. (scrapers), but each of these constituted a very small proportion of the assemblage (Fig. 3b).

The Spearman's correlations (Tab. 3) showed that the biomass of two taxa, $C$. riparius and $G$. cauliginellus, was positively correlated with transported particulate organic matter (TPOM). G. cauliginellus was also positively correlated with macrophyte cover. Orthocladius/Cricotopus spp. was strongly negatively correlated with both water temperature and the amount of coarse particulate organic matter (CPOM) as well as negatively correlated with phosphorus and positively with nitrogen. 
Table 3. Spearman's correlation between biomass of three dominant chironomid taxa and environmental parameters in the macrophytes of the tailwater of the Warta River. $\mathrm{T}$ - water temperature, $\mathrm{O}_{2}$ - dissolved oxygen, $\mathrm{TN}$ - total nitrogen, TP - total phosphorus, CPOM - coarse particulate organic matter, FPOM - fine particulate organic matter, TPOM - transported particulate organic matter, SAM - submersed aquatic macrophytes; d w - dry weight. Values statistically significant are bolded.

\begin{tabular}{|c|c|c|c|c|c|c|c|c|}
\hline \multirow[b]{2}{*}{ Chironomid taxa } & \multicolumn{8}{|c|}{ Parameters } \\
\hline & $\begin{array}{c}\mathrm{T} \\
\left({ }^{\circ} \mathrm{C}\right)\end{array}$ & $\begin{array}{c}\mathrm{O}_{2} \\
\left(\mathrm{mg} \mathrm{L}^{-1}\right)\end{array}$ & $\begin{array}{c}\mathrm{TN} \\
\left(\mathrm{mg} \mathrm{L}^{-1}\right)\end{array}$ & $\begin{array}{c}\mathrm{TP} \\
\left(\mathrm{mg} \mathrm{L}^{-1}\right)\end{array}$ & $\begin{array}{c}\text { CPOM } \\
\left(\mathrm{g} \mathrm{d} \mathrm{w} \mathrm{m}^{-2}\right)\end{array}$ & $\begin{array}{c}\text { FPOM } \\
\left(\mathrm{g} \mathrm{d} \mathrm{w} \mathrm{m}^{-2}\right)\end{array}$ & $\begin{array}{c}\text { TPOM } \\
\left(\mathrm{g} \mathrm{d} \mathrm{w} \mathrm{m}^{-2}\right)\end{array}$ & $\begin{array}{c}\text { SAM } \\
\left(\mathrm{g} \mathrm{d} \mathrm{w} \mathrm{m}^{-2}\right)\end{array}$ \\
\hline Orthocladius/Cricotopus spp. & $-0.933^{* *}$ & 0.633 & $0.967^{* *}$ & $-0.933^{* *}$ & $-0.769^{*}$ & -0.167 & -0.483 & 0.486 \\
\hline Chironomus riparius Meigen & 0.217 & -0.033 & -0.150 & 0.333 & 0.410 & 0.283 & $0.750^{*}$ & 0.771 \\
\hline Glyptotendipes cauliginellus (Kieffer) & 0.450 & -0.067 & -0.200 & 0.367 & 0.594 & 0.450 & $0.683^{*}$ & $0.829^{*}$ \\
\hline
\end{tabular}

${ }^{*} p<0.05,{ }^{* *} p<0.01$.

\subsection{Spatial and trophic preferences, production of chironomids associated with SAM}

The main food categories of the dominant chironomid taxa associated with the two parts of sago were POM, algae (mainly diatoms) and bacteria (Fig. 2). Scrapers (i.e. Orthocladius/ Cricotopus spp.) fed on epiphyton, while gathering collectors (G. cauliginellus and C. riparius) fed on sediment trapped by the roots (benthos).

Epiphyton scrapers achieved the highest values of production (Tab. 2). Their main representative, Orthocladius/Cricotopus spp., are taxa characterized by individuals of medium body size, with short development time (CPI). The other abundant trophic group was that of large-sized benthic gathering collectors, including $C$. riparius and G. cauliginellus, which were less productive due to lower CPIs in comparison with the former taxon.

\section{Discussion}

\subsection{Chironomid assemblages in macrophytes}

The body size, density, biomass, production or biomass/ production ratio of microbenthic assemblages may be calculated for various biotic and abiotic profiles, such as habitat patches, chosen systematic groups, i.e. chironomids, trophic groups, or body size groups (Lindegaard, 1989; Grzybkowska et al., 1996; Benke, 1998), supplying much contrasting outcomes. The body size spectrum of freshwater macroinvertebrates, for example, rises monotonically from microbiota to about $1 \mathrm{mg}$ wet weight, such as that of chironomid larvae and tubificids, which are dominant groups in freshwater ecosystems (Strayer, 1991; Grzybkowska et al., 2017, 2018). This is in contrast to marine zoobenthos, where organisms may range 10 orders of magnitude (Schwinghamer, 1981), yet freshwater body size is important enough to strongly affect development time (CPI) and consequently production $(\mathrm{P})$. The most important aspects of chironomids in the epiphytic and benthic habitats are discussed below in detail.

The density of the epiphytic dominant, Orthocladius/ Cricotopus spp., was on average fifty times that of the benthic dominant, $C$. riparius, while the density of the latter was only about twice higher than that of the benthic subdominant, $C$. cauliginellus. The ranges of density values obtained on the nine sampling occasions were wide in all three species, but the variances of the values were roughly similar (Tab. 1).

The biomass of the epiphytic dominant was about ten times higher than that of the benthic dominant, and 15 times than of the benthic subdominant. Interestingly, the proportion of our biomass values are a bit different from the biomass proportions usually observed between chironomid subfamilies. Data from the literature indicate that Chironominae species usually display higher biomass (range $0.1-1.0 \mathrm{~g}$ wet weight, and values over $1.0 \mathrm{~g}$ constituting a significant proportion $(24 \%$ of total chironomid biomass)), while those of Orthocladiinae are usually in the range $0.01-1.0 \mathrm{~g}$, with few species between $1.0 \mathrm{~g}$ and $10 \mathrm{~g}$ (only in the large-sized Cricotopus and Glyptotendipes). However, values above $10.0 \mathrm{~g}$ are much rarer among Chironominae than among Orthocladiinae (Tokeshi, 1995).

In the case of our three dominant species, biomass results are much higher than those reported in the literature, yet this to some extent results from the values being calculated for the SAM period of May-August and not for the whole year. If we recalculated the values for a whole year by multiplying them by the ratio of the time length of the period to the whole year (i.e. by assuming that the biomass in all other months was none), the value of Orthocladius/Cricotopus spp. biomass would amount to ca. $30 \mathrm{~g}$, which is higher than the highest annual mean biomass observed by Iwakuma (1986) for a large, univoltine species of Tokunagayusurika akamusi from Lake Kasumigaura, Japan, which was $11 \mathrm{~g}$. The Orthocladius/ Cricotopus spp. biomass value that we obtained is particularly higher than values recorded in all other streams, because they never exceeded $1 \mathrm{~g}$ (Tokeshi, 1995). These high values of our dominant chironomids indicate the unusual importance of the SAMs for chironomid development.

The highest values of annual production reported to date for orthoclads in the literature are those of Chaetocladius melaleucus in an artificial recirculating stream in England (11$25 \mathrm{~g} \mathrm{~d} \mathrm{w} \mathrm{m}^{-2} \mathrm{yr}^{-1}$, Ladle et al., 1984) and Tokunagayusurika akamusi in Lake Kasumigaura, Japan (18 g, Iwakuma, 1986). However, Tokeshi (1996) reported a production of Orthocladius $(\mathrm{O})$ sp. in a 30 meter long stretch of the small Tud River in England between 1 March and 31 May that after recalculating for the whole year (July 1983-June 1984), and assuming no production occurred in the other months of that year, would amount to $23.0 \mathrm{~g} \mathrm{~d} \mathrm{w} \mathrm{m}^{-2}$. These comparisons again indicate the importance of the Warta SAM for the productivity of the ecosystem. The production of benthic Chironominae 
subdominant, G. cauliginellus, and benthic Chironominae subdominant, $C$. riparius was similar, and would reach about $15 \mathrm{~g} \mathrm{~d} \mathrm{w} \mathrm{m}^{-2} \mathrm{yr}^{-1}$ after a recalculation for a whole year.

The production/biomass ratio of the epiphytic habitat dominant, Orthocladius/Cricotopus spp., was more than twice that of the benthic dominant and subdominant. The ranges of $\mathrm{P} / \mathrm{B}$ values recorded in the literature are very wide in the case of both Orthocladiinae and Chironominae, the highest ever recorded amounting to over 300 in the case of the former subfamily, and to over 150 in the case of the latter subfamily (Benke et al., 1984). However, in chironomid communities Chironominae $\mathrm{P} / \mathrm{B}$ values are usually higher than those of Orthocladiinae, which is the opposite in our research.

\subsection{Macrophytes and other productive habitats}

Riverine sediment overgrown by SAM is a rich habitat (Lindegaard, 1989; Grzybkowska et al., 2003, 2017). It results from the faunal community inhabiting macrophytes, which vary considerably over time and among patches, reflecting phenological shifts and biomass of plants, succession changes of invertebrate taxa, and micro-scale variations in water velocity (Collier, 2004). It is often considered as a much more productive habitat than nearby unvegetated sediment (Franklin et al., 2008; Kleeberg et al., 2010; Tóth et al., 2012). As shown in our earlier investigations this phenomenon is typical of this stretch of the Warta River (Grzybkowska et al., 2003, 2018). It has to be borne in mind that although SAMs are very productive in tailwaters, they are not the only productive habitats in rivers in general.

A high correlation between macrophytes and Orthocladiinae (scrapers) is usually recorded. However, our study also indicated a stronger correlation between pelophilous Glyptotendipes and plants. This latter phenomenon may be related to the trapping of fine particulate organic matter (of reservoirorigin) by submersed macrophytes, which accumulates on the bottom, among roots and becomes the preferred habitat for Glyptotendipes (Grzybkowska et al., 2017).

Other such rich habitats are shallow areas with coarse sediments and large amounts of periphyton (Bournaud et al., 1998; Lindegaard, 1989), and deeper zones with a gravel substrate abundant in organic particles. These kinds of sediments may provide some protection against large predators for animals small enough to fit in the interstice shelters (Strayer, 1991). Still other productive riverine microhabitats are sandy patches covered by mud (Lindegaard, 1989); our earlier results confirmed these findings (Grzybkowska and Witczak, 1990; Grzybkowska et al., 1996, 2017). As Lindegaard (1989) showed in his review paper, the lowest macroinvertebrate production in lotic ecosystems was recorded in riffles with stones.

Dominant chironomid taxa associated with the SAMs represent different trophic groups. One such group, which includes Orthocladius/Cricotopus (Orthocladiinae), are mainly periphyton scrapers (feeding on algae). Another group, gathering collectors (Chironomini, benthic forms) feed on sediment food resources: fine POM with algae and bacteria. Thus their trophic and spatial preferences partially overlap. However, the numbers of bacteria associated with POM in the alimentary tracts of these two species were different. What are the reasons for this difference? Does Chironomus, which exhibits great flexibility in its mode of feeding (deposit or filter-feeding; Berg, 1995), utilize a fraction and/or layer of POM in a different way from Glyptotendipes? On the basis of our data this question remains unanswered.

\subsection{The invertebrates' life strategies}

An interesting phenomenon affecting the biomass and productivity of benthic macroinvertebrate animals is bioturbation (Nogaro et al., 2006), which is especially important in ecosystems with a thick layer of fine POM accumulated on the sediment. Bioturbation consists of macroinvertebrate processing of the sediment, i.e. in digging canals in the sediment that affect the exchange of nutrients between the sediment and the water column. Although both Chironomidae and Tubificidae do this, the two taxa create different structures: chironomids make U-shaped canals (either one or both ends of which penetrate(s) the surface of the sediment), while tubificids make long galleries (mostly in fine sediment), creating pathways for water flow, which reduces the clogging of sediment. Both animal groups contribute to the exchange of matter and energy between the benthos and water column by ingesting mud and egesting faecal pellets above the sediment surface.

However, depending on the oxygen contents and other factors, chironomids typically stay in their U-shaped tubes, while tubificids quickly move through benthos, leaving their galleries for water flow. In other words, tubificids maintain high hydraulic conductivity, which contributes to increased water-sediment exchange and stimulates biogeochemical and microbial processes. In contrast, the U-shaped tubes of chironomids are restricted to the superficial layer of fine POM and do not modify the hydraulic conductivity of sediments (Nogaro et al., 2006). Consequently, there seems to be no or little spatial competition between these two groups; they appear to coexist in a way that intensifies the productivity of the whole environment in cases such as that of the presently discussed macrophyte overgrown tailwater. Nevertheless, the problem of spatial habitat overlap in SAMs, and in particular among the roots and stems of sago, is more complicated due to the fact that two dominant Chironomini species (C. riparius and $G$. cauliginellus) co-occur in the root zone, while Orthocladius/Cricotopus spp. dwell in a separate habitat of sago stems.

On the basis of the food preference of dominant small and/ or young abundant teleost fishes (ruffe, perch and roach) living in this macrophyte stretch of the Warta River, we can state that they are able to forage successfully on zooplankton of reservoir origin as well as on chironomids independently of their mode of life (Lik et al., 2017). Selective predation by fish on both benthic burrowers, such as large-sized $G$. cauliginellus, and $C$. riparius and/or epiphytic tube-dwelling forms living on shoots, choosing large-sized prey items from each ecological group was recorded (Lik et al., 2017). Thus the wide variety of behaviors, morphologies and other biological traits by which many benthic macroinvertebrates (including chironomids) are characterized in comparison with zooplankton help them avoid being preyed on by other aquatic animals, but are not efficient 
enough to completely protect them (Strayer, 1991; Gyllström et al., 2005).

To conclude, the high production of each dominant chironomid taxon investigated is the result of several phenomena: the contrasting exploitation of the different parts of aquatic plants, and food resource partitioning between orthoclad scrapers and Chironomini gathering collectors seems the most important of them.

Acknowledgements. We are grateful to our colleagues and students from the Department of Ecology and Vertebrate Zoology UŁ for assistance in the field and/or laboratory analysis of macroinvertebrate samples. Special thanks are directed to Carl Smith (UK) for suggestions on an earlier version of this manuscript, and to Rowena Spence (UK) for correcting the presently revised version of the ms. We also thank the Department of Hydrography and Morphology of River Beds, the Institute of Meteorology and Water Management, Poland, for granting us a license to use the Electronic Map of Hydrographic Partitions in Poland. This work was partly supported by the University of Lodz Grant No. 505/424.

\section{References}

Armitage PD, Cranston PS, Pinder LCV. 1995. The Chironomidae. The biology and ecology of non-biting midges. London: Chapman \& Hall.

Benke AC. 1979. A modification of the Hynes method for estimating secondary production with particular significance for multivoltine populations. Limnol Oceanogr 24: 168-171.

Benke AC. 1998. Production dynamics of riverine chironomids: extremely high biomass turnover rates of primary consumers. Ecology 79: 899-910.

Benke AC, Van Arsdall TC, Gillespie DM. 1984. Invertebrate productivity in a subtropical blackwater river: the importance and life history. Ecol Monogr 54: 25-63.

Berg MB. 1995. Larval food and feeding behaviour. In Armitage PD, Cranston PS, Pinder LCV, eds. The Chironomidae. The biology and ecology of non-biting midges. London: Chapman \& Hall, 136-168.

Bournaud M, Tachet H, Berly A, Cellot B. 1998. Importance of microhabitat characteristics in the macrobenthos microdistribution of a large river reach. Ann Limnol - Int J Lim 34: 83-98.

Collier KJ. 2004. Invertebrate community dynamics in soft-bottomed streams of northern New Zealand: a spatio-temporal hierarchy. New Zeal J Mar Fresh 38: 1-18.

Cushman RM, Shugart Jr HH, Hildebrand SG, Elwood JW. 1978. The effects of growth curve and sampling regime on instantaneous growth, removal-summation, and Hynes/Hamilton estimates of aquatic insect production: a computer simulation. Limnol Oceanogr 23: 184-189.

Czarnecka H. 2005. Atlas of Poland's Hydrographic Partitions. Warsaw: Institute of Meteorology and Water Management.

Franklin P, Dunbar M, Whitehead P. 2008. Flow controls on lowland river macrophytes: A review. Sci Total Environ 400: 369-378.

Grzybkowska M, Witczak J. 1990. Distribution and production of Chironomidae (Diptera) in the lower course of the Grabia River (Central Poland). Freshwat Biol 24: 519-531.

Grzybkowska M, Głowacki Ł. 2011. Chironomidae (Diptera) diversity in lowland rivers of various orders and of different levels of human impact in central Poland. In Wang X, Liu W, eds. Contemporary chironomid studies. Proceeding of the 17th
International Symposium on Chironomidae, Tianjin, China, July 6-9, 2009. Tianjin: Nankai University Press, 282-295.

Grzybkowska M, Temech A, Dukowska M. 1996. Chironomid production in four lowland rivers (Central Poland). Pol Arch Hydrobiol 43: 245-256.

Grzybkowska M, Dukowska M, Takeda AM, Majecki J, Kucharski L. 2003. Seasonal dynamics of macroinvertebrates associated with submersed macrophytes in a lowland river downstream of the dam reservoir. Ecohydrol Hydrobiol 3: 399-408.

Grzybkowska M, Kucharski L, Dukowska M, Takeda AM, Lik J, Leszczyńska J. 2017. Submersed aquatic macrophytes and associated fauna as an effect of dam operation on a large lowland river. Ecol Eng 99: 256-264.

Grzybkowska M, Dukowska M, Leszczyńska J, Lik J, SzczerkowskaMajchrzak E, Przybylski M. 2018. The food resources exploitation by small-sized fish in a riverine macrophyte habitat. Ecol Indic 90: 206-214.

Gyllström M, Hansson LA, Jeppesen E, et al. 2005. The role of climate in shaping zooplankton communities of shallow lakes. Limnol Oceanogr 50: 2008-2021.

Hamilton AL. 1969. On estimating annual production. Limnol Oceanogr 14: 771-782.

Hynes HBN, Coleman MJ. 1968. A simple method of assessing the annual production of stream benthos. Limnol Oceanogr 13: 569573.

IMGW - Institute of Meteorology and Water Management in Poland. 2007. EMPHP - Electronic Map of Hydrographic Partitions in Poland. URL: http://www.imgw.pl (last accessed 10 Jan 2016).

Iwakuma T. 1986. Ecology and production of Tokunagayusurika akamusi (Tokunaga) and Chironomus plumosus (L.) (Diptera: Chironomidae) in a shallow eutrophic lake. Ph.D. thesis, Kyushu University, Japan.

Kleeberg A, Köchler J, Sukhodolova T, Sukhodolov A. 2010. Effects of aquatic macrophytes on organic matter deposition, resuspension and phosphorus entrainment in a lowland river. Freshwat Biol 55: 326-345.

Konstantinov AS. 1958a. Biologija chironomid i ich razwedene. Trudy Saratov Otd Kasp Fil 5: 1-363.

Konstantinov AS. 1958b. The influence of temperature on the rate of growth and development of chironomid larvae. Doki Akad Nauk SSSR 120: 1362-1365.

Krebs CJ. 2014. Ecology: The Experimental Analysis of Distribution and Abundance. Harlow: Pearson Education Limited.

Ladle M, Welton JS, Bass JAB. 1984. Larval growth and production of three species of Chironomidae from an experimental recirculating stream. Arch Hydrobiol 102: 201-214.

Lik J, Dukowska M, Leszczyńska J, Grzybkowska M. 2017. Summer co-existence of small-sized cyprinid and percid individuals in natural and impounded stretches of a lowland river: food niche partitioning among fish. J Fish Biol 90: 1609-1630.

Lindegaard C. 1989. A review of secondary production of zoobenthos in freshwater ecosystems with special reference to Chironomidae (Diptera). Acta Biol Debr Oecol Hung 3: 231-240.

Mackey AP. 1977. Growth and development of larval Chironomidae. Oikos 28: 270-275.

Moller Pillot HKM. 2009. Chironomidae larvae. Vol. 2. Biology and ecology of the Chironomini. Zeist: KNNV Publishing.

Nogaro G, Mermillod-Blondin F, François-Carcaillet F, et al. 2006. Invertebrate bioturbation can reduce the clogging of sediment: an experimental study using infiltration sediment columns. Freshwat Biol 51: 1458-1473.

Nolte U. 1990. Chironomid biomass determination from larval shape. Freshwat Biol 24: 443-451. 
Petersen RC, Cummins KW, Ward GM. 1989. Microbial and animal processing of detritus in a woodland stream. Ecol Monogr 59: 21-39.

Porter KG, Feig YS. 1980. The use of DAPI for identifying and counting aquatic microflora. Limnol Oceanogr 25: 943-948.

Schwinghamer P. 1981. Characteristic size distributions of integral benthic communities. Can J Fish Aquat Sci 38: 1255-1263.

StatSoft Inc. 2011. STATISTICA (data analysis software system), version 10.0. Tulsa, USA: StatSoft Inc.

Strahler AN. 1957. Quantitative analysis of watershed geomorphology. Trans Am Geophys Union 38: 913-920.

Strayer DL. 1991. Perspectives on the size structure of lacustrine zoobenthos, its causes, and its consequences. J North Am Benthol Soc 10: 210-221.

Tokeshi M. 1995. Chapter 11. Production Ecology. In Armitage PD, Pinder LC, Cranston PS, eds. The Chironomidae. The biology and ecology of non-biting midges. London: Chapman \& Hall, 269-296.

Tokeshi N. 1996. Resource utilization, overlap and temporal community dynamics: a null model analysis of an epiphytic chironomid community. J Anim Ecol 55: 491-506.
Tóth M, Móra A, Kiss B, Dévai G, Specziár A. 2012. Are macrophyte-dwelling Chironomidae (Diptera) largely opportunistic in selecting plant species? Eur J Entomol 109: 247-260.

Vander Zanden HB, Soto DX, Bowen GJ, Hobson KA. 2016. Expanding the isotopic toolbox: 410 applications of hydrogen and oxygen stable isotope ratios to food web studies. Front Ecol Evol 4: 20

Van Donk E, Van de Bund WJ. 2002. Impact of submerged macrophytes including charophytes on phyto- and zooplankton communities: allelopathy versus other mechanisms. Aquat Bot 72: 261-274.

Vellend M. 2016. The theory of ecological communities. Princeton: Princeton University Press.

VIEP - Voivodeship Inspectorate for Environmental Protection in Lodz. 2019. https://www.wios.lodz.pl/ (last accessed 31 May 2019).

Wagner A, Volkmann S, Dettinger-Klemm PMA. 2012. Benthicpelagic coupling in lake ecosystems: the key role of chironomid pupae as prey of pelagic fish. Ecosphere 3: 1-17.

Waters TF. 1977. Secondary production in inland waters. Advan Ecol Res 10: 91-164.

Cite this article as: Grzybkowska M, Leszczyńska J, Głowacki Ł, Szczerkowska-Majchrzak E, Dukowska M, Szelagg-Wasielewska E. 2020. Some aspects of the ecological niche of chironomids associated with submersed aquatic macrophytes in a tailwater. Knowl. Manag. Aquat. Ecosyst., 421, 22. 